\title{
Therapeutic Potential of Apigenin, a Plant Flavonoid, for Imatinib-Sensitive and Resistant Chronic Myeloid Leukemia Cells
}

\author{
Soner Solmaz \\ Department of Hematology, Adana Teaching and Medical Research Center, Baskent University, \\ Adana, Turkey
}

Aysun Adan Gokbulut

Department of Molecular Biology and Genetics, İzmir Institute of Technology, İzmir, Turkey

\section{Birsu Cincin}

Department of Molecular Medicine, Institute of Experimental Medical Research, Istanbul University, Istanbul, Turkey

\author{
Hakan Ozdogu and Can Boga \\ Department of Hematology, Adana Teaching and Medical Research Center, Baskent University, \\ Adana, Turkey
}

\section{Bedia Cakmakoglu}

Department of Molecular Medicine, Institute of Experimental Medical Research, Istanbul University, Istanbul, Turkey

\section{Ilknur Kozanoglu}

Cell Processing Unit, Adana Adult Bone Marrow Transplantation Center, Baskent University, Adana, Turkey and Department of Physiology, Medical Faculty, Baskent University, Ankara, Turkey

\section{Yusuf Baran}

Department of Molecular Biology and Genetics, İzmir Institute of Technology, Izmir, Turkey

Despite the presence of many therapeutic regimens like imatinib and other tyrosine kinase inhibitors, the development of resistance, intolerance, and side effects makes chronic myeloid leukemia (CML) therapy challenging. Thus, there is a need to discover novel drugs for CML patients. In this study, we attempted to assess apigenin, a common plant dietary flavonoid, in terms of its cytotoxic, apoptotic, and cytostatic effects on imatinib-sensitive and resistant Philadelphia-positive CML cells. We analyzed apigenin's effects on cell proliferation, apoptosis, caspase-3 activity, loss of mitochondrial membrane potential, and cell cycle progression in K562 and K562/IMA3 cells. Furthermore, we described genes and

Submitted 17 July 2013; accepted in final form 20 November 2013. Address correspondence to Yusuf Baran, Izmir Institute of Technology, Department of Molecular Biology and Genetics, 35430 Urla, İzmir, Turkey. Phone: + 90232 7507315. Fax: + 902327507302. E-mail: yusufbaran@iyte.edu.tr gene networks that are modulated in CML in response to apigenin. Results of our study revealed that apigenin has cytotoxic and apoptotic effects on both cell types. We also displayed that apigenin induced G2/M arrest in K562 cells while arresting K562/IMA3 cells in $S$ phase especially at the highest apigenin concentration. The expression analysis identified a set of genes that were regulated by apigenin in K652 and K562/IMA3 cells. Association of modulated genes with biological functional groups identified several networks affected by apigenin including cell survival, proliferation, cell death, cell cycle, and cell signalling pathways.

\section{INTRODUCTION}

Chronic myeloid leukemia (CML), a hematological disorder, is defined by a reciprocal translocation between the breakpoint cluster (BCR) gene on chromosome 22 and the abelson leukemia virus oncogene (ABL) gene on chromosome 9 (1). BCR-ABL1 fusion gene encoding the chimeric BCR-ABL1 
oncoprotein with constitutive tyrosine kinase activity has been generated as a molecular consequence of this translocation (1). The exact role of BCR-ABL protein in myeloid proliferation and transformation in CML has been studied in several in vivo and in vitro models of tumor development (2). Oncogenic BCR-ABL has been shown to possess antiapoptotic activity (3). BCR-ABL triggers the activation of many signaling pathways by interacting with several effector molecules and promotes proliferation and genetic instability while suppressing apoptosis and weakening cellular adhesion (4). In the clinic, tyrosine kinase inhibitors (TKIs) are used for the treatment of CML and contribute the quality of patient's life (5). Imatinib mesylate, a first-generation tyrosine kinase inhibitor, is used for first-line therapy in CML due to its great efficacy (6). Despite its therapeutic efficacy, the development of imatinib-resistance and intolerance is still a challenging problem for most patients (7). Many novel compounds and therapeutic approaches are currently being investigated preclinically and clinically to overcome imatinib resistance (8). Dasatinib and nilotinib are the second generation TKIs that are more effective and safer in patients with imatinib-resistance and intolerance (8). However, the development of novel Bcr-Abl mutants resistant to these new small-molecule inhibitors and adverse effects of these agents are still significant problems (9).Therefore, alternative therapeutic approaches are required and natural products have been investigated because of their potential in cancer prevention and treatment.

Flavonoids are a family of polyphenolic compounds that are common components of the human diet. They are widely distributed in the plant kingdom and occur naturally in a broad range of fruits and vegetables. Currently, there is a growing interest in polyphenolic phytochemicals, including flavonoids, because experimental and epidemiological data support that they exert many beneficial effects including antioxidant, antiinflammatory, cardioprotective, and anticarcinogenic activities (10-12). Apigenin (4',5,7-trihydroxyflavone), a common plant dietary flavonoid, is present at high levels in several fruits and vegetables, has been paid attention as an alternative anticancer compound, but its mechanism of action remains unclear and shows variation between different cancer types (13). The mechanisms of apigenin-induced apoptosis include stimulation of gap junctional communication, inhibition of transformation, angiogenesis, and activation of nuclear transcription factor kappa $\mathrm{B}$ $(\mathrm{NF}-\kappa \mathrm{B})(14)$. Morover, apigenin has been reported to induce apoptosis through caspase- $3,-8$, and -9 (15-17). Apigenin treatment has been also shown to alter the Bax/Bcl-2 ratio in favor of apoptosis $(11,12)$. The growth inhibitory and apoptotic effects of apigenin on several human cancer types, including breast, lung, colon, liver, and certain hematologic cancer cells have been studied (18-20), but there is a lack of studies related with the effects of apigenin in CML.

Herein, we aim to examine the cytotoxic, apoptotic, and cytostatic effects of apigenin on imatinib-sensitive and resistant, Philadelphia-positive K562 CML cells. In the present article we also describe genes and networks that are modulated in CML following treatment with apigenin.

\section{MATERIALS AND METHODS}

\section{Chemicals}

Apigenin was obtained from Santa Cruz Biotechnology, Inc. (Heidelberg, Germany). The stock solution of apigenin was dissolved in dimethylsulfoxide (DMSO) at a concentration of $10 \mathrm{mM}$, stored at $-20^{\circ} \mathrm{C}$, and diluted in blank cell culture medium. The final concentration of DMSO did not exceed more than $0.1 \%$ in culture. Penicillin-streptomycin, RPMI 1640, and fetal bovine serum were obtained from Invitrogen (Paisley, UK).

\section{Cell Lines and Culture Conditions}

Human K562 CML cells were obtained from German Collection of Microorganisms and Cell Cultures (Braunschweig, Germany). K562 cells were maintained in RPMI 1640 growth medium containing $10 \%$ fetal bovine serum and $1 \%$ penicillinstreptomycin at $37^{\circ} \mathrm{C}$ in $5 \% \mathrm{CO}_{2} . \mathrm{K} 562$ cells grown in RPMI 1640 were exposed to increasing concentrations of imatinib, starting with $50 \mathrm{nM}$. At the end of this process, $3 \mu \mathrm{M}$ imatinib resistant cells were generated and named as K562/IMA3 cells (21).

\section{Measurement of Cell Growth by MTT Assay}

Antiproliferative effects of apigenin on K562 and K562/IMA3 CML cells was determined by MTT cell proliferation assay. In short, $2 \times 10^{4}$ cells/well were seeded into 96-well plates containing $100 \mu 1$ of the growth medium in the absence or presence of increasing concentrations of apigenin and then incubated at $37^{\circ} \mathrm{C}$ in $5 \% \mathrm{CO}_{2}$ for 48 and $72 \mathrm{~h}$. After incubation period, the cells were treated with $20 \mu \mathrm{l}$ MTT for $3 \mathrm{~h}$. Then, plates were centrifuged for $10 \mathrm{~min}$ at $580 \mathrm{~g}$. After centrifugation, supernatants were removed from the plates and then the MTT crystals were homogenized by adding $100 \mu \mathrm{l}$ DMSO into each well. To homogenize the pellets more efficiently, the plates were shaken for $5 \mathrm{~min}$ by shaker. Afterwards, the plates were read under $570 \mathrm{~nm}$ wavelengths by Elisa reader (Thermo Electron Corporation Multiskan Spectrum, Vantaa, Finland). Finally, IC50 value (drug concentration inhibits cell growth by 50\%) of apigenin was calculated according to the cell proliferation plots (22).

\section{Analysis of Apoptotic Cells by AnnexinV-FITC/PI Double Staining}

We determined the translocation of phosphatidylserine from the inner membrane to the outer cell membrane in order to examine apoptotic effects of apigenin on both sensitive and imatinib-resistant CML cells. Initially, $1 \times 10^{6}$ cells were treated with different concentrations of apigenin for $72 \mathrm{~h}$. After incubation period, the cells were washed twice with cold PBS and then homogenized with $1 \mathrm{~mL}$ of $1 \mathrm{X}$ binding buffer. Then, $100 \mu \mathrm{l}$ of this solution were added into glass tubes. $5 \mu \mathrm{l}$ of FITC Annexin $\mathrm{V}$ and $5 \mu \mathrm{l}$ of propidium iodide (PI) were added onto 
the cell solutions. These samples were vortexed gently and then incubated for $15 \mathrm{~min}$ at room temperature in the dark. Afterwards, $400 \mu 1$ of $1 \mathrm{X}$ binding buffer were added to each tube, and then they were analyzed by flow cytometry (BD Facscanto Flowcytometry, Erembodegem, Belgium) within $1 \mathrm{~h}$.

\section{Analysis of the Changes in Mitochondrial Membrane Potential}

We examined the loss of mitochondrial membrane potential (MMP) in response to apigenin in both cells by JC-1 Mitochondrial Membrane Potential Detection Kit (Cayman Chemicals, Ann Arbor, MI). This kit uses a unique cationic dye, JC-1, to signal the loss of MMP. JC-1 accumulates in mitochondria, which stain red in nonapoptotic cells while in apoptotic cells, MMP collapses, and thus JC- 1 dye remains in the cytoplasm as a monomer that stains green under fluorescent light. Briefly, the cells $\left(1 \times 10^{6}\right.$ cells $\left./ 2 \mathrm{~mL}\right)$, induced to undergo apoptosis, were collected by centrifugation at $400 \mathrm{~g}$ for $10 \mathrm{~min}$. Supernatants were removed and pellets were homogenized by $300 \mu \mathrm{l}$ of medium. Thirty $\mu \mathrm{l}$ of JC- 1 dye were added onto the cells and the cells were incubated at $37^{\circ} \mathrm{C}$ in $5 \% \mathrm{CO}_{2}$ for $30 \mathrm{~min}$. Then, they were centrifuged at $400 \mathrm{~g}$ for $5 \mathrm{~min}$, supernatants were removed and $200 \mu 1$ of assay buffer were added onto the pellets and vortexed. Then, this step was repeated once again. Afterwards, all pellets were homogenized with $320 \mu \mathrm{l}$ assay buffer and $100 \mu \mathrm{l}$ from each of them were added into 96-well plate as triplicates. The aggregate red form has absorption/emission maxima of 560/595 nm, whereas the monomeric green form has absorption/emission maxima of $485 / 535 \mathrm{~nm}$. The plate was read in these wavelengths by fluorescence Elisa reader (Thermo Varioskan Spectrum, Finland). At the end, the ratio of fluorescent intensity of JC-1 monomers (green) to fluorescent intensity of JC-1 aggregates (red) were calculated for each concentration as well as untreated control sample. Then, relative changes in cytoplasmic/mitochondrial JC-1 were determined by comparing to control samples (23).

\section{Analysis of Caspase-3 Activity}

Changes in caspase- 3 activity of the cells were examined by caspase-3 colorimetric assay kit (BioVision Research Products, Milpitas, CA). This assay is based on spectrophotometric detection of the chromophore $p$-nitroanilide $(p \mathrm{NA})$ after cleavage from the labeled substrate DEVD- $p$ NA that can be recognized by caspases. In short, the cells $\left(1 \times 10^{6}\right.$ cells $/ 2 \mathrm{~mL} /$ well $)$, induced to undergo apoptosis by apigenin, were collected by centrifugation at $400 \mathrm{~g}$ for $10 \mathrm{~min}$. The cells were lysed by adding $50 \mu \mathrm{l}$ of chilled Cell Lysis Buffer and incubated on ice for $10 \mathrm{~min}$ before centrifugation at 10,000 $\mathrm{g}$ for $1 \mathrm{~min}$. Supernatants were transferred to new eppendorf tubes and the reaction mixture was prepared in 96-well plates by adding $50 \mu \mathrm{l}$ of $2 \mathrm{X}$ Reaction Buffer (containing $10 \mathrm{mM}$ DTT), $50 \mu \mathrm{l}$ of sample, and $5 \mu \mathrm{l}$ of DEVD-pNA substrate and incubated for $2 \mathrm{~h}$ at $37^{\circ} \mathrm{C}$ in $\mathrm{CO}_{2}$ incubator. At the end of this period, the plate was read under $405 \mathrm{~nm}$ wavelengths by Elisa reader (Thermo Electron Corpo- ration Multiskan Spectrum, Vantaa, Finland). The absorbance values were normalized to protein concentrations determined by Bradford assay.

\section{Cell Cycle Analysis}

This technique is based on the determination of amounts of dsDNA by using PI, a DNA-binding dye, through flow cytometry. When the data acquired from the flow cytometry are analyzed, cell cycle phases and the amounts of fragmented DNA of the cells can be determined. Briefly, $1 \times 10^{6}$ cells $/ 2 \mathrm{~mL}$ were treated with increasing concentrations of apigenin for $72 \mathrm{~h}$. After the incubation period, cells were collected by centrifugation at $400 \mathrm{~g}$ for $10 \mathrm{~min}$. Supernatants were removed, and pellets were homogenized with $1 \mathrm{~mL}$ cold PBS, and then the samples were put on ice. Afterwards, although the cells were slightly vortexed, $4 \mathrm{~mL}$ of cold ethanol were added onto these cells, and then put on ice. Fixated cells by this method were incubated overnight at $-20^{\circ} \mathrm{C}$ for the analysis. Next day, the cells were centrifuged at $400 \mathrm{~g}$ for $10 \mathrm{~min}$, and supernatants were completely removed from the pellets. Pellets were homogenized with $1 \mathrm{~mL}$ cold PBS, and centrifuged again at $400 \mathrm{~g}$ for $10 \mathrm{~min}$. Afterwards, cell pellets were homogenized with $1 \mathrm{~mL}$ PBS containing $0.1 \%$ triton $\mathrm{X}-100$, and then $100 \mu \mathrm{l}$ RNase $\mathrm{A}(200 \mu \mathrm{g} / \mathrm{mL})$ were added onto these cells, and they were incubated at $37^{\circ} \mathrm{C}$ for $30 \mathrm{~min}$. After this incubation period, $100 \mu \mathrm{l}$ PI $(1 \mathrm{mg} / \mathrm{mL})$ were added onto the cells. These cells were incubated at room temperature for 15 min and then analyzed by flow cytometry.

\section{Microarray Analysis}

Total RNA was isolated from K562 and K562/IMA3 cells exposed to $50 \mu \mathrm{M}$ and $100 \mu \mathrm{M}$ Apigenin for $72 \mathrm{~h}$ using High Pure RNA Isolation Kit (Roche, San Francisco, CA) according to manufacturer's instructions. The concentrations and purities of RNA samples were measured with NanoDrop (Thermo Scientific, Wilmington, DE) spectrophotometer (260/280 nm ratios) and only the samples with an A260/A280 ratio between 1.9 and 2.1 were considered for further use. Illumina Human HT-12v4 beadchip microarrays (containing $\sim 47,000$ transcripts: $\sim 30000$ genes) (Illumina, Inc., San Diego, CA) were used to assess global gene expression for each sample. Five hundred ng of total RNA were firstly reverse-transcribed into cDNA and then cDNA samples were converted to biotin-labeled cRNA by using the Illumina TotalPrep RNA-amplification kit (Ambion, Foster City, CA) based on manufacturer's instructions for hybridization analysis. Then, $1.5 \mu \mathrm{g}$ of labeled cRNA was hybridized to each array according to the Illumina whole-genome gene expression direct hybridization assay protocol. Arrays were scanned using the Illumina BeadArray Reader. The images were processed and converted into signal intensities using the Illumina GenomeStudio software (Illumina, Inc., San Diego, CA). The same software was used to perform hybridization quality control (QC).

\section{Statistical Analysis}

Statistical significance was determined using one-way analysis of variance (ANOVA) for MTT analyses, and 2-way ANOVA 
for Annexin V, MMP, and caspase-3 activity analyses. $P<0.05$ was considered to be significant. The signal intensities corresponding to gene expression levels were background corrected and imported into text files using the Illumina GenomeStudio. Hierarchical cluster analysis was applied to data sets to evaluate the "proximity" between genes and hierarchical clusters were constructed with the statistically significant $(P<$ $0.05)$ genes. Genes were considered differentially expressed when logarithmic gene expression ratios in 3 independent hybridizations were more than 1.5 or less than 0.66 and when the $P$ values were less than 0.05 . Gene ontology and pathway analyses were performed to consider biological meaning of differential expression of genes between the treated and untreated samples by using the Kyoto Encyclopedia of Genes and Genomes and Ingenuity Pathway Analysis (IPA; Ingenuity Systems, Redwood City, CA).

\section{RESULTS}

\section{Cytotoxic Effects of Apigenin on Both K562 and K562/ IMA3 Cells}

Our previous findings demonstrated that K562/IMA3 cells $\left(\mathrm{IC}_{50}: 14680 \mathrm{nM}\right)$ were around 52-fold more resistant to imatinib as compared to sensitive $\mathrm{K} 562$ cells $\left(\mathrm{IC}_{50}: 280 \mathrm{nM}\right)(21)$. Cytotoxic effects of apigenin on K562 and K562/IMA3 cells were determined by MTT cell proliferation assay. $\mathrm{IC}_{50}$ values of apigenin for K562 cells at 48 and $72 \mathrm{~h}$ were calculated from cell proliferation plots and were found to be 16 and $2,5 \mu \mathrm{M}$, respectively (Fig. 1A). On the other hand, $\mathrm{IC}_{50}$ values of apigenin for K562/IMA3 cells were found to be 65 and $63 \mu \mathrm{M}$ at indicated time points, respectively (Fig. 1B). These results demonstrated that apigenin has cytotoxic effects on both cell types in a timeand dose-dependent manner. However, K562/IMA3 cells were 4- and 25-fold more resistant to apigenin as compared to K562 cells at 48 and $72 \mathrm{~h}$, respectively.

\section{Apigenin Induces Apoptosis of Both K562 and K562/ IMA3 Cells in a Dose-Dependent Manner}

Apoptotic effects of apigenin on both cells were determined by Anexin-V/PI double staining. The percentage of apoptotic cell population of sensitive and resistant cells treated with increasing concentrations of apigenin was determined by flow cytometry. Although no significant changes were detected in apoptotic cells up to $20 \mu \mathrm{M}$ apigenin, there were 2.6- and 4.2fold increases in percentage of apoptotic K562 cells in response to 50 and $100 \mu \mathrm{M}$ apigenin, respectively, as compared to untreated controls (Fig. 2A and Fig. 2B). On the other hand, 50 and $100 \mu \mathrm{M}$ apigenin caused 1.1- and 2.2- fold increases in apoptotic K562/IMA3 cell population (Fig. 2C and 2D). These results indicated that apigenin increased apoptotic cell population at higher concentrations in both cell lines but K562/IMA3 cells showed resistance to apigenin as compared to K562 cells.

\section{Apigenin Induces Loss of MMP in Both K562 and K562/ IMA3 Cells in a Dose-Dependent Manner}

Loss of mitochondrial membrane potential is an important sign of apoptosis because it has been linked to initiation and activation of apoptotic cascades. Therefore, we determined whether apigenin causes the loss of MMP in both cell lines exposed to the same concentrations of apigenin. The results revealed that there were 1.3-, 1.7-, 2-, 2.1-, and 2.3-fold increases in loss of MMP in K562 cells treated with 5, 10, 20, 50, and $100 \mu \mathrm{M}$ apigenin, respectively, as compared to untreated controls. The same concentrations of apigenin led to 1.18-, 1.19-, 1.24, 1.3, and 1.41-fold increases in loss of MMP in K562/ IMA3 cells, respectively, as compared to untreated controls (Fig. 3).

\section{Apigenin Increases Caspase-3 Activity in a Dose- Dependent Manner in Both K562 and K562/IMA3 Cells}

Caspase- 3 enzyme has a central role in the mitochondrialmediated cell death. To determine whether apoptosis induced by apigenin was associated with activation of caspase-3, the cells were treated with increasing concentrations of apigenin for $72 \mathrm{~h}$ and the changes in caspase- 3 enzyme activity was detected through the cleavage of the labeled substrate DEVD$p$ NA. There were 1.02-, 1.2-, 1.26-, and 1.9-fold increases in caspase- 3 enzyme activity in response to 5, 10, 20, and $50 \mu \mathrm{M}$ apigenin in K562 cells, respectively, as compared to untreated controls (Fig. 4A). On the other hand, the same concentrations of apigenin increased caspase-3 enzyme activity 1.07-, 1.08-, 1.28, and 1.54-fold in K562/IMA3 cells exposed to the same concentrations of apigenin as compared to control, respectively (Fig. 4B). K562/IMA3 cells were also treated with $100 \mu \mathrm{M}$ apigenin and there was only a 1.86 -fold increase in caspase- 3 activity. Apigenin increased caspase- 3 activity in a dose-dependent manner with no significant changes in K562 and K562/IMA3 cells.

\section{Apigenin Arrested Cell Cycle Progression in G2/M Phase in K562 Cells but not in K562/IMA3 Cells}

To determine the possible mechanism of antiproliferative activity of apigenin, cell cycle progression of both cell lines were examined by flow cytometry in the presence of DNase free RNase and PI dye. As summarized in Fig. 5A, treatment of K562 cells with apigenin resulted in small increases in the percentage of cells in the $\mathrm{G} 2 / \mathrm{M}$ phase at 5 to $20 \mu \mathrm{M}$ apigenin but in response to $100 \mu \mathrm{M}$ apigenin there was a significant increase. In accordance with this result, there were also decreases in the percentage of the cells in G0/G1 and S phases. On the other hand, there was no significant effect of apigenin on G2/M phase of K562/IMA3 cell cycle (Fig. 5B). However, K562/IMA3 cells arrested in $\mathrm{S}$ phase especially at $100 \mu \mathrm{M}$ apigenin. 


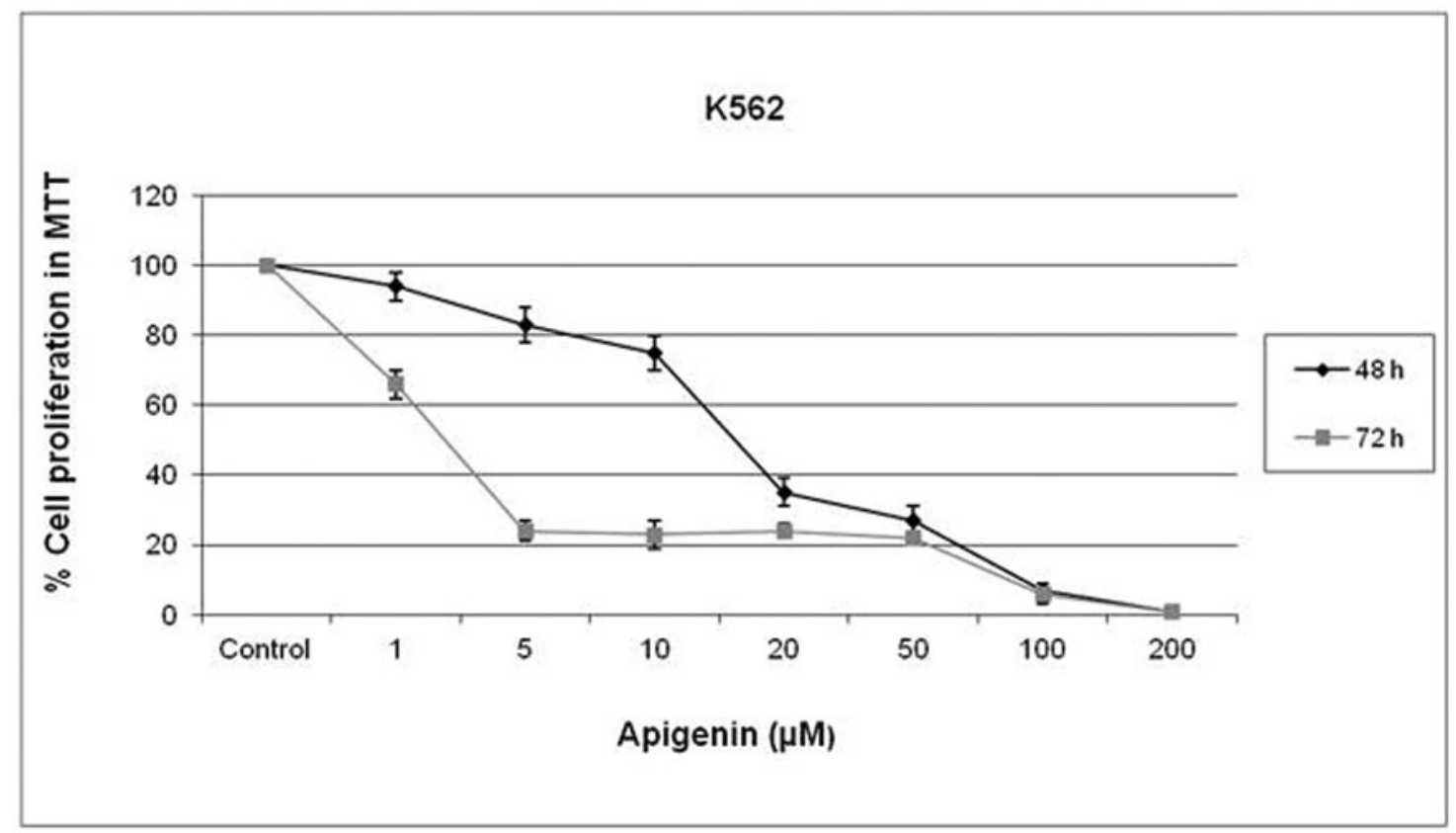

A

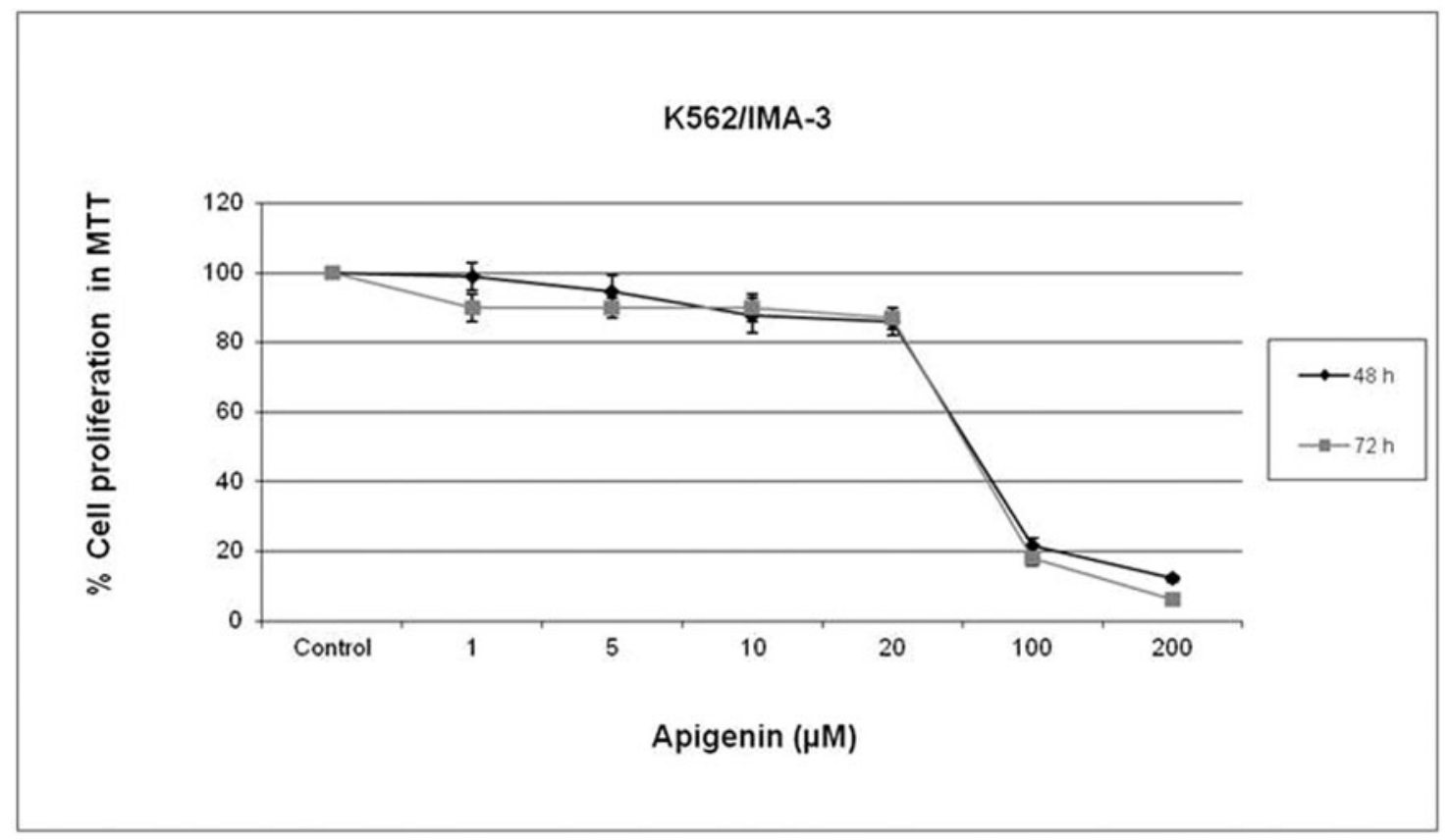

B

FIG. 1. Cytotoxic effects of apigenin on human K562 (A) and K562/IMA3 (B) chronic myeloid leukemia (CML) cells. The IC50 value of apigenin was calculated from cell proliferation plots. The results are the means of 3 independent experiments. The error bars represent the standard deviations. Statistical significance was determined using one-way analysis of variance and $P<0.05$ was considered to be significant.

Identification of Genes Differentially Expressed in Apigenin Treated Imatinib-Sensitive and Resistant CML Cells

We examined the changes in expression levels of the genes following treatment of K562 and K562/IMA3 cells with 50 and $100 \mu \mathrm{M}$ apigenin. Isolated total RNA was amplified and converted to biotin-labeled cRNA, which was hybridized to microarray system containing approximately 30,000 genes. Hierarchical clustering of gene expression (heat map analysis) in untreated and apigenin treated K562 and K562/IMA3 cells 


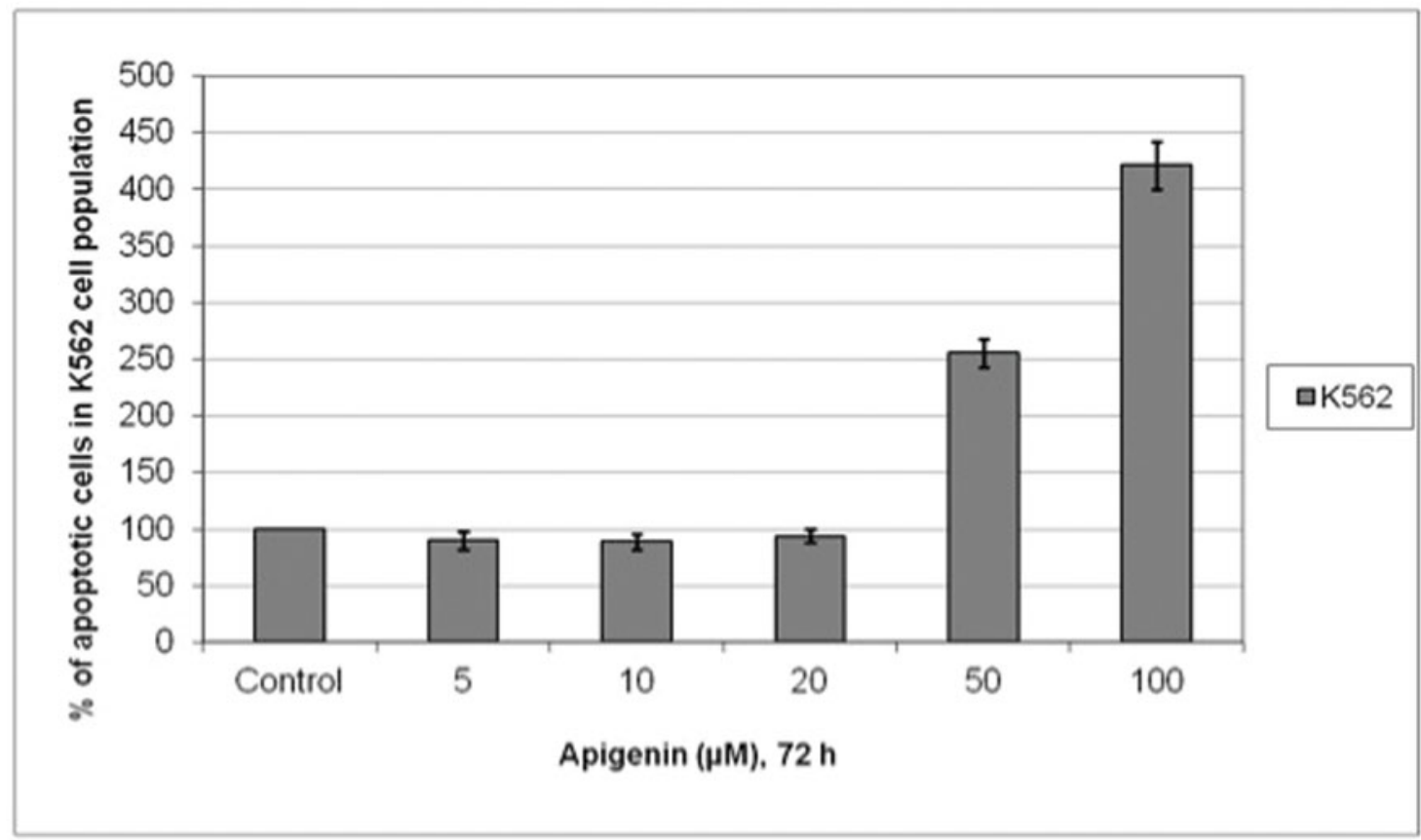

A
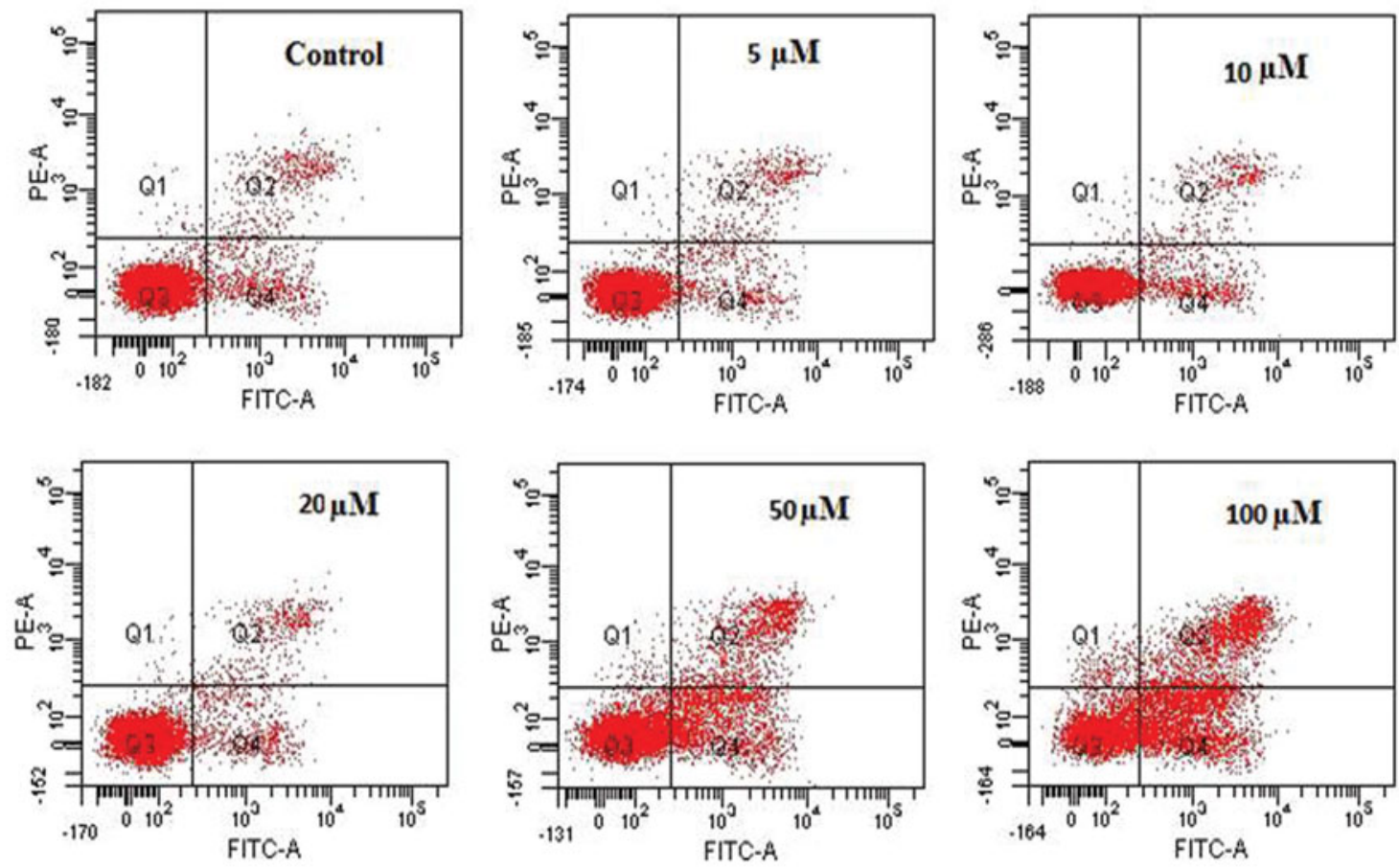

K562

B

FIG. 2. Evaluation of apoptosis in sensitive and resistant cells induced by apigenin. The percentage of cells undergoing apoptosis in a dose-dependent manner as compared to control and FACS analysis via Annexin V-FITC/propidium iodide (PI) staining (A and B for K562 cells, C and D for K562/IMA3 cells). Cells in the lower right quadrant indicate Annexin-positive/PI negative, early apoptotic cells. The cells in the upper right quadrant indicate Annexin-positive/PI positive. The percentage of cells annexin V positive, PI positive, or double positive for both annexin V and PI is indicated. The results are the means of 3 independent experiments. (Color figure available online.) 

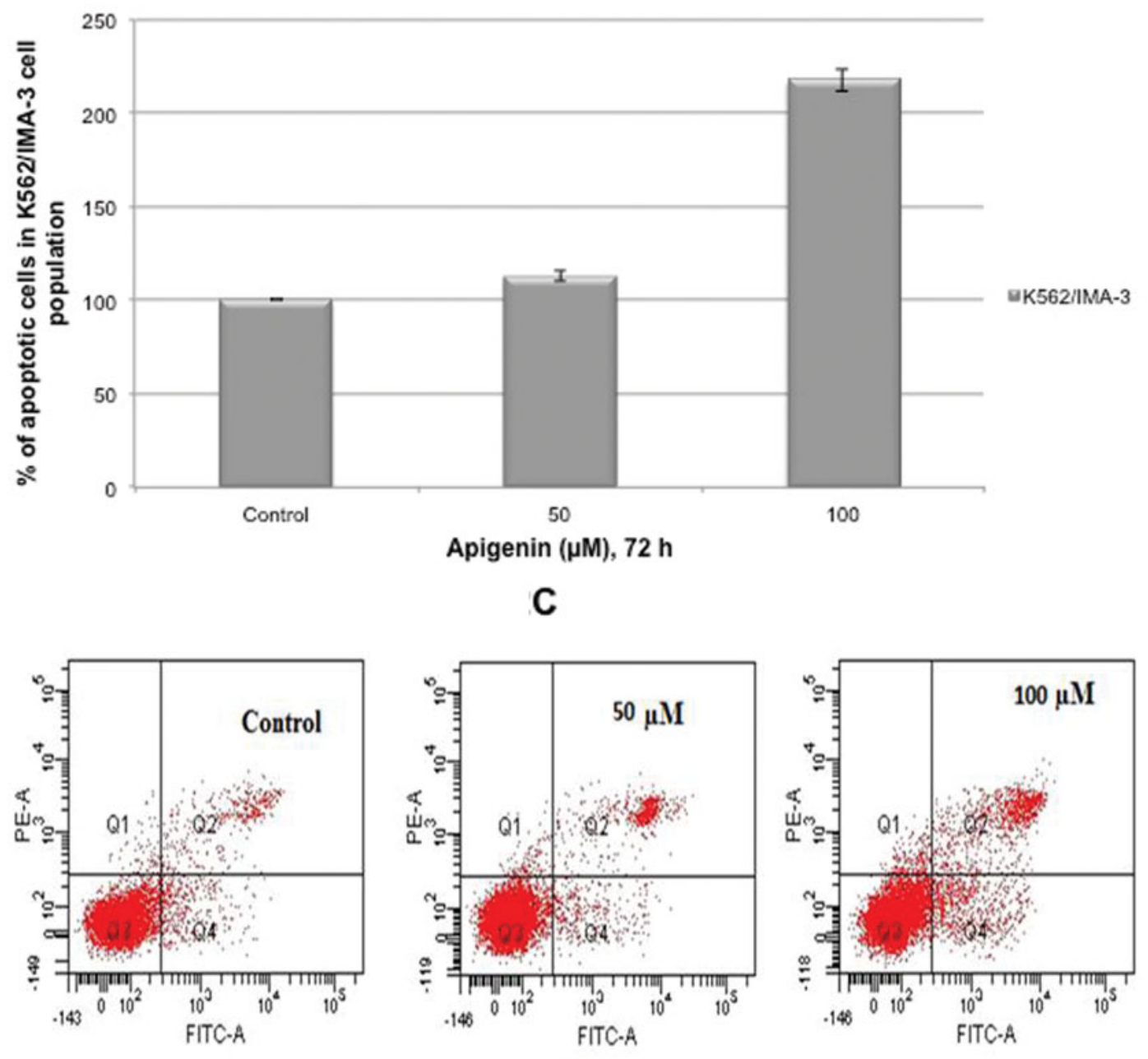

K562/IMA-3

D

FIG. 2. (Continued)

is shown in Fig. 6A. total of 1526 and 1368 genes were significantly regulated $(P<0.05)$ in 50 and $100 \mu \mathrm{M}$ apigenin treated K562 sensitive cells, respectively. The number of genes upregulated were 674 whereas those of downregulated were 852 in $50 \mu \mathrm{M}$ apigenin-treated $\mathrm{K} 562$ cells. In $100 \mu \mathrm{M}$ apigenin treated K562 cells, 676 genes were upregulated and 692 genes were downregulated. Moreover, a total of 315 genes were common between 50 and $100 \mu \mathrm{M}$ apigenin-treated sensitive cells. On the other hand, a total of 1485 (778 genes upregulated, 707 downregulated) and 2442 genes (1176 genes were upregulated, 1266 genes were downregulated) were significantly changed $(P<0.05)$ in response to 50 and $100 \mu \mathrm{M}$ apigenin in K563/IMA-3 cells, respectively. A total of 455 genes were common between 50 and $100 \mu \mathrm{M}$ apigenin-treated imatinib resistant cells. Fold-change analysis showed that UNC5A (netrin receptor), PDCD1LG2 (programmed cell death 1 ligand
2), BCAM (basal adhesion molecule), SCARA5 (scavenger receptor class A, member 5), and DGKA (diacylglycerol kinase alpha) were the examples of altered genes in both 50 and $100 \mu \mathrm{M}$ apigenin treated sensitive cells (Table 1). Table 2 illustrates the examples of genes altered after apigenin treatment in K562/IMA3 cells. It was clear that HAGH (hydroxyacylglutathione hydrolase or glyoxylase II), IL15RA (interleukin 15 receptor, alpha), ENTPD1 (ectonucleoside triphosphate diphosphohydrolase 1), and DGKI (diacylglycerol kinase iota) were the examples of upregulated genes in both 50 and $100 \mu \mathrm{M}$ apigenin-treated K562/IMA3 cells.

\section{Identification of Genetic Networks Affected by Apigenin}

To examine the affected genetic networks after apigenin treatment, we carried out pathway analysis using the IPA tool. These networks describe functional relationships between gene 
TABLE 1

The genes altered $\geq$ twofold after apigenin treatment of K562 sensitive cells

\begin{tabular}{|c|c|}
\hline $\begin{array}{l}\text { Altered genes in } 50 \mu \mathrm{M} \\
\text { apigenin-treated K562 } \\
\text { sensitive cells (Fold changes) }\end{array}$ & $\begin{array}{c}\text { Altered genes in } 100 \mu \mathrm{M} \\
\text { apigenin-treated K562 } \\
\text { sensitive cells (Fold changes) }\end{array}$ \\
\hline UNC5A (42.440) & UNC5A $(32.340)$ \\
\hline PDCD1LG2 (16.818) & PDCD1LG2(18.015) \\
\hline HES2 (5.659) & $\operatorname{BCAM}(5.044)$ \\
\hline BCAM (4.226) & SNAI1(4.777) \\
\hline NPTX1 (4.201) & MOB4(4.272) \\
\hline SCARA5 (3.957) & LOXL4(3.477) \\
\hline PRKAG2 (2.982) & SCARA5(3.181) \\
\hline miR-15 (2.049) & $\operatorname{miR}-195(2.782)$ \\
\hline PCSK6 (-24.088) & ADAMTS13(2.266) \\
\hline KIF12 (-8.070) & PPP1R9A(-31.415) \\
\hline EIF3C/EIF3CL(-7.747) & CD74(-14.305) \\
\hline UGT1A6 (-6.812) & EPHA5(-4.640) \\
\hline REPS2 (-5.261) & BRAF $(-2.076)$ \\
\hline CALML6 (-2.559) & FYN(-2.313) \\
\hline PRKCB (-2.285) & IL8(-2.456) \\
\hline DGKA (-2.179) & $\operatorname{DGKA}(-2.288)$ \\
\hline
\end{tabular}

Boldface type represents some genes induced in both 50 and $100 \mu \mathrm{M}$ apigenin-treated K562 cells.
TABLE 2

The genes altered twofold after apigenin treatment of K562/IMA3 imatinib resistant cells

\begin{tabular}{lc}
\hline $\begin{array}{l}\text { Altered genes in } 50 \mu \mathrm{M} \\
\text { apigenin treated K562/IMA-3 }\end{array}$ & $\begin{array}{c}\text { Altered genes in } 100 \mu \mathrm{M} \\
\text { apigenin treated K562/IMA-3 } \\
\text { cells (fold changes) }\end{array}$ \\
cells (fold changes)
\end{tabular}

\begin{tabular}{l}
\hline HAGH (21.248) \\
IL15RA (18.2591) \\
ENTPD1 (7.485) \\
TRAF5 (5.634) \\
DISC1 (5.593) \\
RPE65 (5.380) \\
MEX3D (5.203) \\
ITGB5 (4.768) \\
DGKI (2.574) \\
MAL2 (-27.736) \\
BCAS1 (-12.817) \\
RHOBTB1 (-4.728) \\
MMRN1 (-3.910) \\
FOXA2 (-3.785) \\
PKIG (-2.962)
\end{tabular}

HAGH(22.630)

IL15RA(10.215)

DISC1(6.221)

$\operatorname{ATR}(6.018)$

ENTPD1(5.906)

CHEK2(3.992)

MRP6(3.203)

MMP17(3.171)

DGKI(2.318)

CYP4Z1(-12.850)

CD86(-8.729)

GAB1(-6.585)

CXCR4 4 (-5.804)

PCNA (-2.299)

SCARA5(-2.469)

Boldface type represents some genes induced in both 50 and $100 \mu \mathrm{M}$ apigenin-treated K562/IMA3 cells.

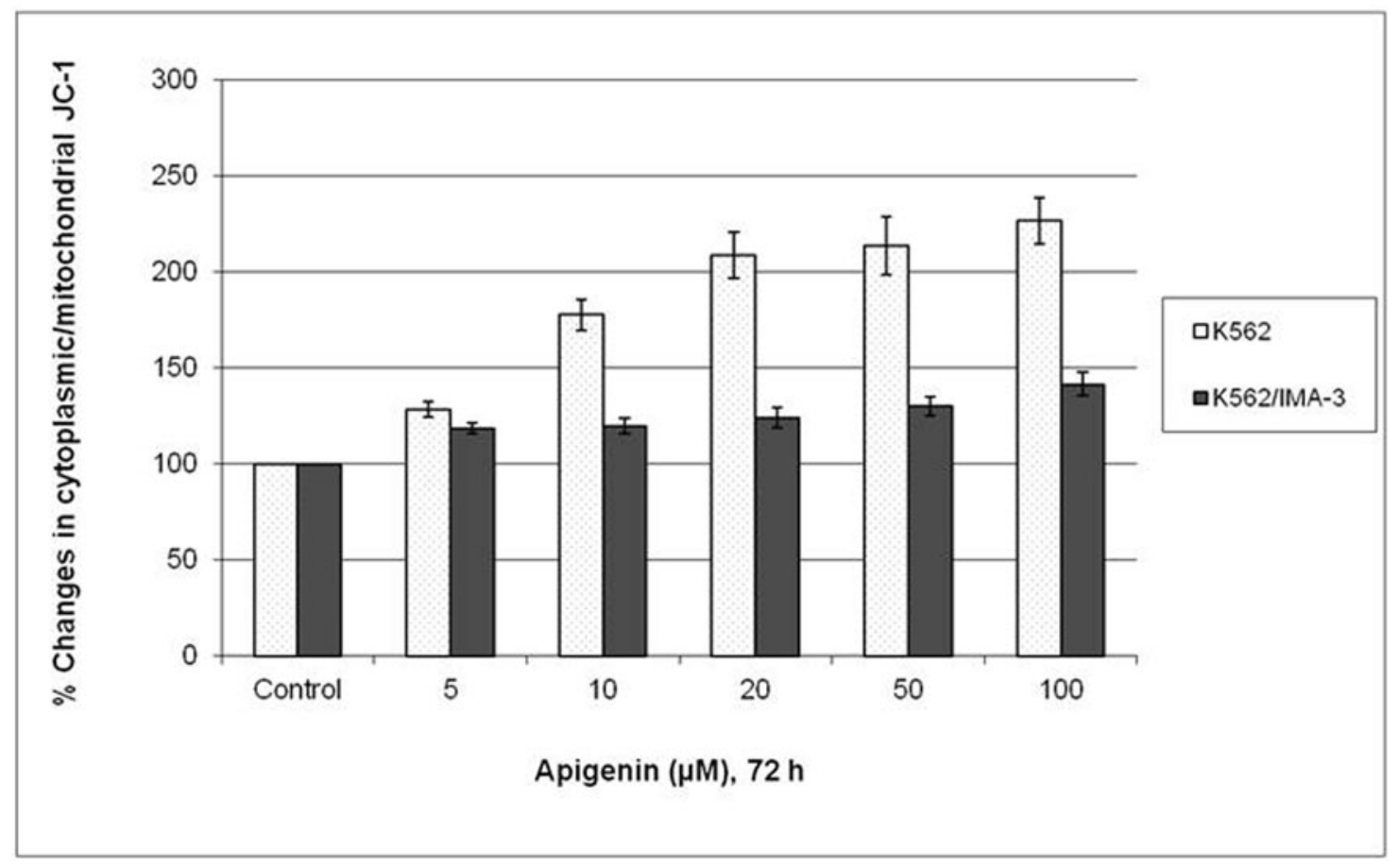

FIG. 3. Percent changes in cytoplasmic/mitochondrial JC-1 in K562 and K562/IMA3 cells treated with increasing concentrations of apigenin. The results are the means of 3 independent experiments. The error bars represent the standard deviations. Statistical significance was determined using 2-way analysis of variance and $P<0.05$ was considered to be significant. 


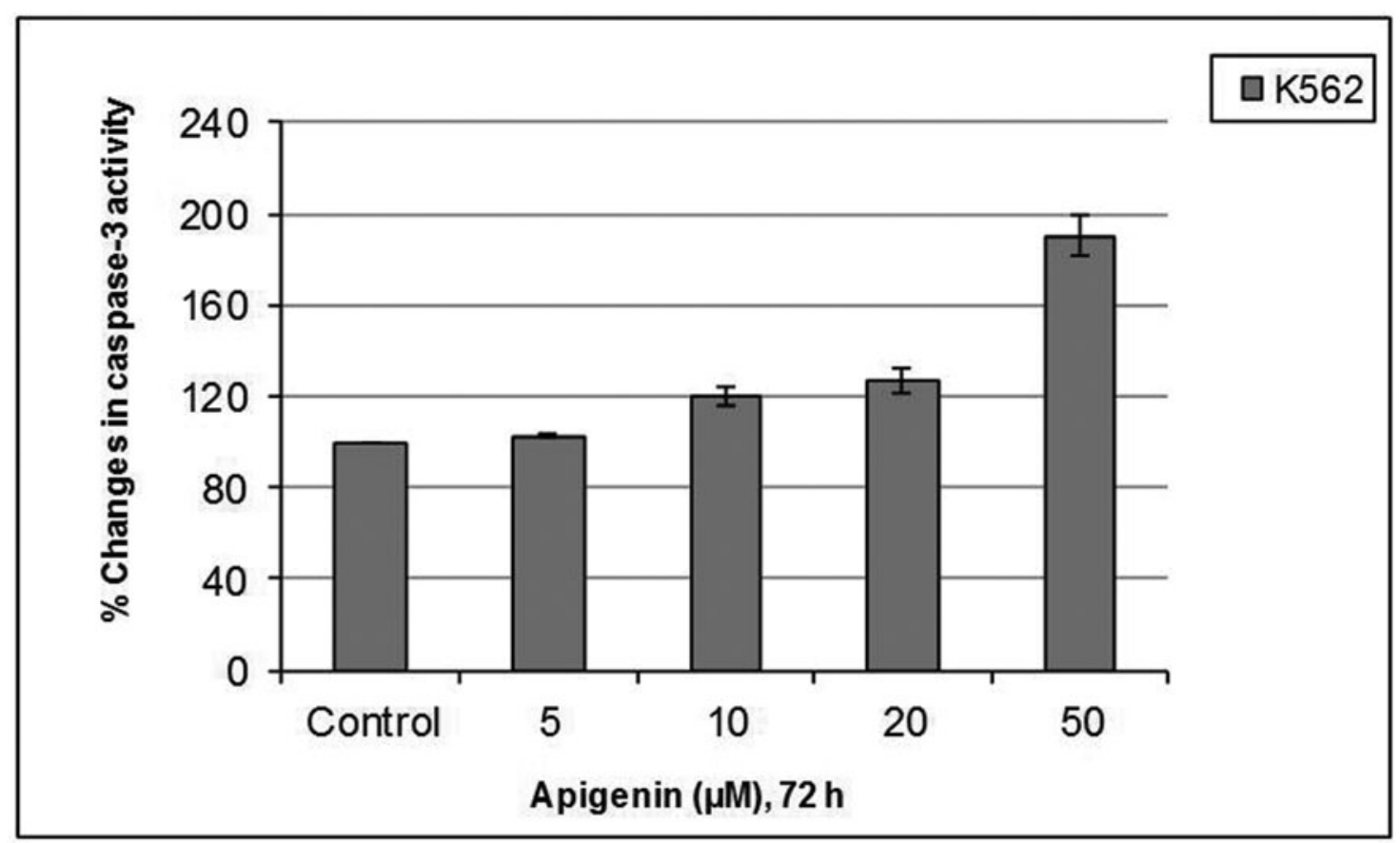

A

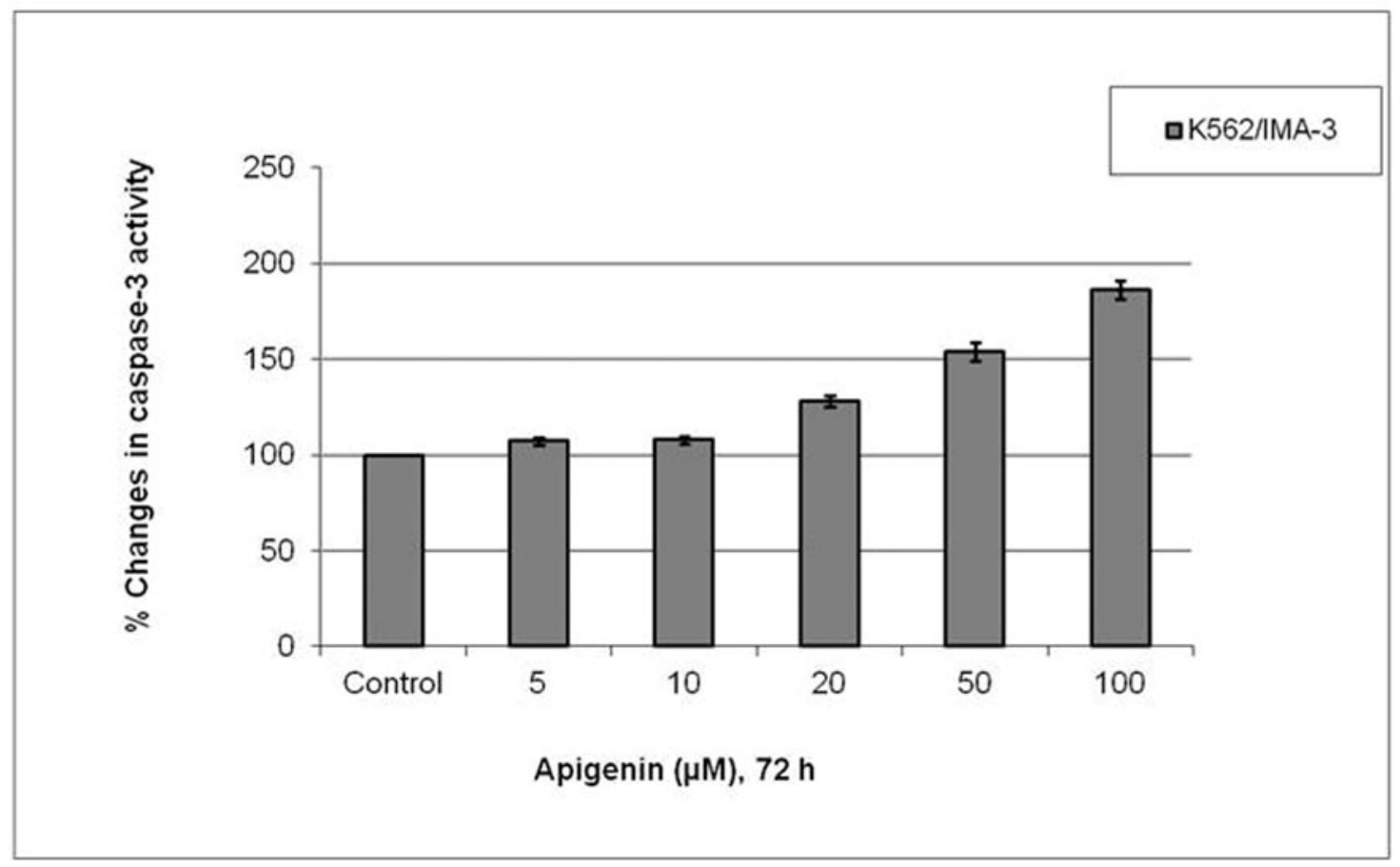

B

FIG. 4. Changes in caspase-3 enzyme activiy in K562 (A) and K562/IMA3 cells (B) in response to apigenin. The results are the means of 3 independent experiments. The error bars represent the standard deviations. Statistical significance was determined using 2 -way analysis of variance and $P<0.05$ was considered to be significant. 


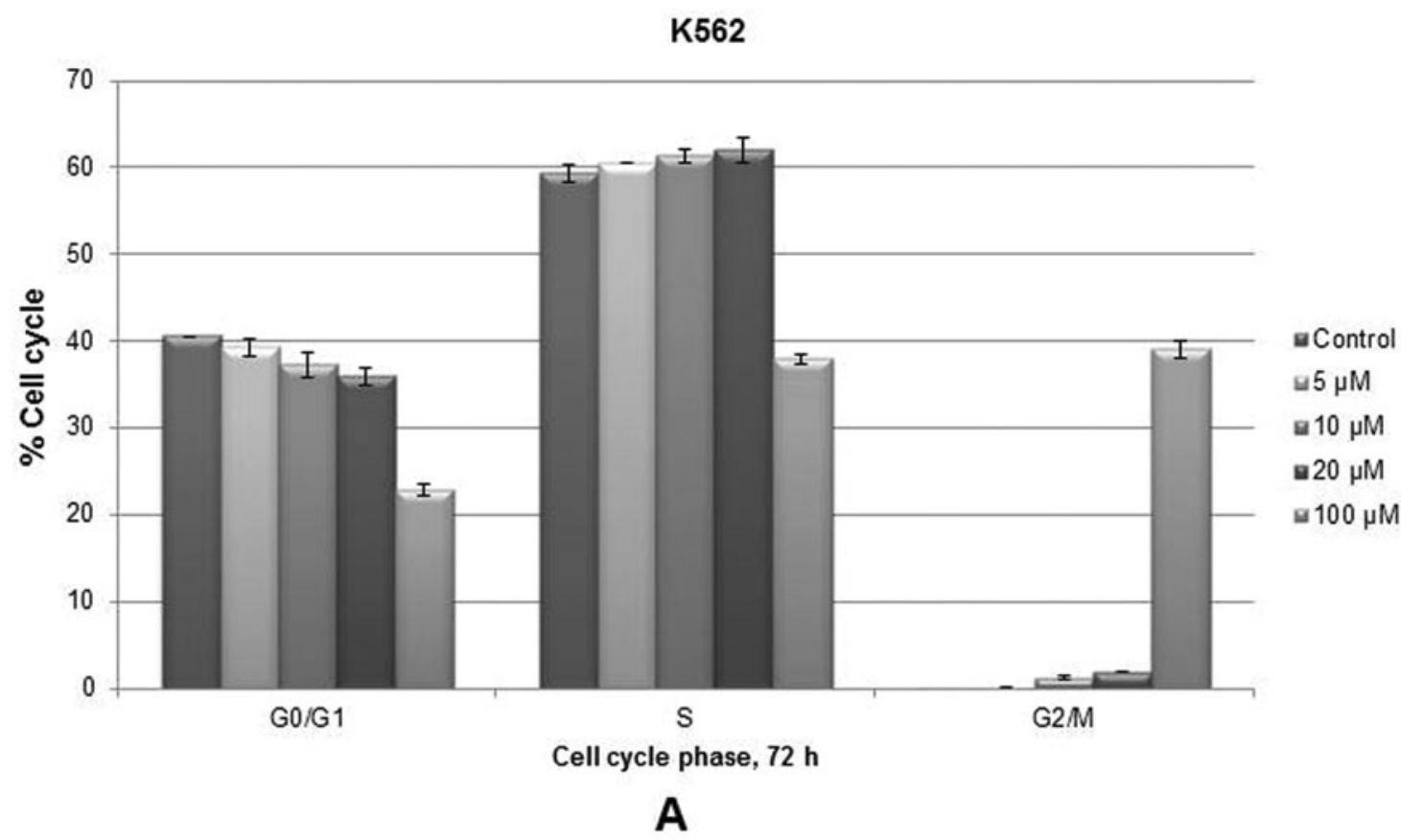

K562/IMA-3

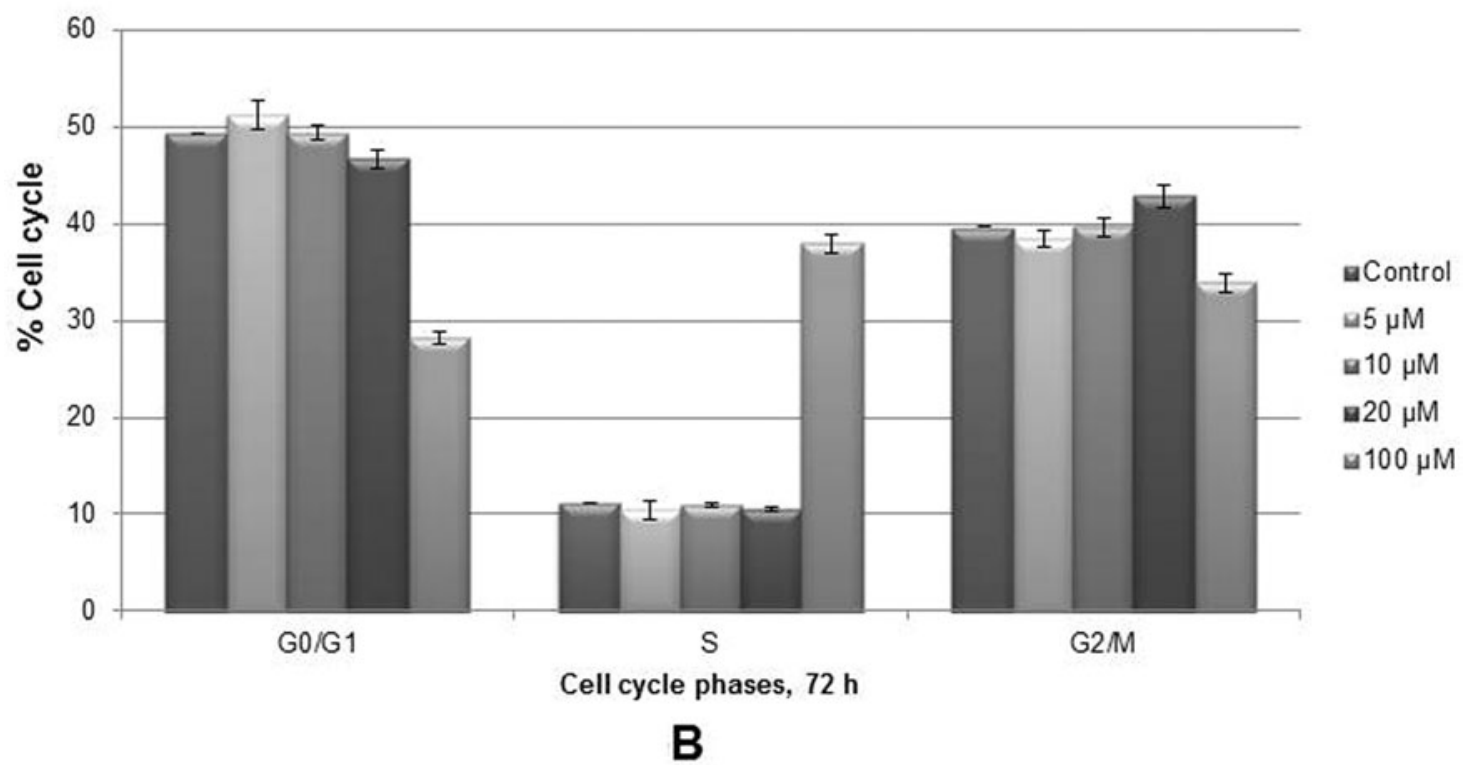

FIG. 5. Effect of apigenin on cell cycle progression. The percentage of cells in cell cycle phases are shown in the graphs (A and B). The results are the means of 3 independent experiments. Statistical significance was determined using 2 -way analysis of variance and $P<0.05$ was considered to be significant.

products based on known interactions in the literature. The results showed that cancer $(P$ value $=1.01 \mathrm{E}-05-3.82 \mathrm{E}-02)$ was the most significant network with 310 affected molecules in $50 \mu \mathrm{M}$ apigenin-treated K562 imatinib sensitive cells. Moreover, cell death and survival with 271 molecules $(P$ value $=5.59 \mathrm{E}-05-3.97 \mathrm{E}-02)$ and cellular development with 242 molecules $(P$ value $=1.52 \mathrm{E}-04-3.62 \mathrm{E}-02)$ were the other most affected networks in $50 \mu \mathrm{M}$ apigenin treated $\mathrm{K} 562$ cells. Similarly, the most affected network in $100 \mu \mathrm{M}$ apigenin treated K562 cells was the cancer with 280 molecules $(P$ value $=2.78 \mathrm{E}-$ $04-3.34 \mathrm{E}-02)$. Cell-to-cell signaling and interaction $(P$ value $=$ 1.32E-04 - 3.30E-02) with 90 molecules and hematological system development and function $(P$ value $=1.89 \mathrm{E}-04-3.32 \mathrm{E}-02)$ with 154 molecules were affected as well as cancer network. On 

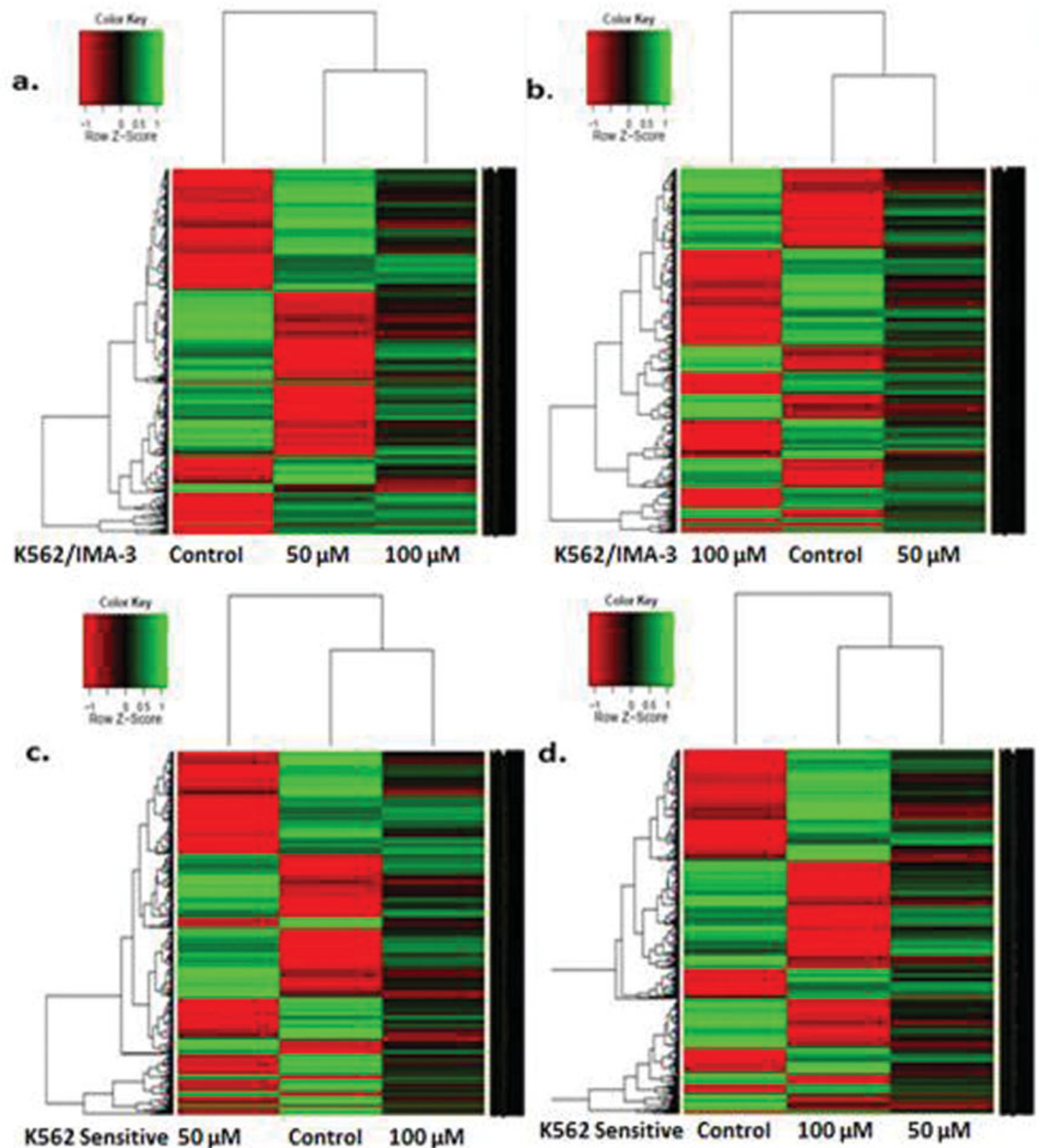

FIG. 6. Hierarchical clustering based on gene expression data from K562 and K562/IMA3 cells exposed to apigenin. Comparison between K562/IMA3 cells treated with $50 \mu \mathrm{M}$ (A) and $100 \mu \mathrm{M}$ (B) apigenin. Comparison between K562 cells treated with $50 \mu \mathrm{M}(\mathrm{C})$ and $100 \mu \mathrm{M}$ (D) apigenin. A fold-change ratio was calculated using the treated sample and its matched untreated sample. Green is downregulated genes and red is upregulated genes. (Color figure available online.)

the other hand, cell-to-cell signaling and interaction $(P$ value $=$ $1.25 \mathrm{E}-06-9.57 \mathrm{E}-03)$, cellular growth and proliferation $(P$ value $=1.06 \mathrm{E}-05-9.57 \mathrm{E}-03)$ and cell signalling $(P$ value $=1.38 \mathrm{E}-05$ $-9.52 \mathrm{E}-03)$ were the significantly altered networks with 155 , 109 , and 84 molecules, respectively, in $50 \mu \mathrm{M}$ apigenin-treated K562/IMA3 cells (Fig. 6). In K562/IMA3 cells treated with $100 \mu \mathrm{M}$ apigenin, cancer $(P$ value $=1.50 \mathrm{E}-06-2.17 \mathrm{E}-02)$, cellular death and survival $(P$ value $=8.84 \mathrm{E}-05-2.16 \mathrm{E}-02)$, cell cycle $(P$ value $=1.06 \mathrm{E}-05-2.21 \mathrm{E}-02)$ and hematological sys- tem development and function ( $P$ value: $1.74 \mathrm{E}-05-2.21 \mathrm{E}-02)$ were changed networks with 511, 443, 112, and 225 molecules, respectively (Fig. 6).

\section{DISCUSSION}

Flavonoids are essential constituents of the human diet and have been suggested to possess anticarcinogenic properties (19). Recently, apigenin, a naturally occurring plant flavone, have 
been found to induce apoptosis in various tumor cells including breast, cervical, lung, ovarian, prostate, liver, and certain leukemias (12). Apigenin induces cell death with variable efficacy in several cancer types including colon, breast cancer, and prostate cancer. Despite its low efficacy in epithelial cells, apigenin induces apoptosis with high efficacy in myelogenous leukemia cells. However, the mechanisms regulating apigenininduced apoptosis in leukemia cells remain elusive $(13,19)$. In recent studies, apigenin has been shown to trigger apoptosis through Hsp27 phosphorylation (20), cytochrome c release (19), caspase activation $(16,19)$, and proteasome inhibition in several leukemic cells (24). We conducted this study to examine the cytotoxic, cytostatic, and apoptotic effects of apigenin on K562 and K562/IMA3 CML cells. We treated the cells with increasing concentrations of apigenin and determined its cytotoxic/antiproliferative effects by MTT cell proliferation assay. The results of this assay revealed that apigenin decreased proliferation of the cells in a dose- and time-dependent manner. It is very well known in the literatüre that cancer cells resistant to any agent may show cross resistance to the others. However, the important point in this study is that although K562/IMA-3 cells are more than around 50 times resistance to imatinib as compared to sensitive cells, they are just 4 times more resistance to apigenin at $48 \mathrm{~h}$. On the other hand, Annexin-V/PI double staining showed increases in apoptotic cell population in both K562 and K52/IMA-3 cells in response to 50 and $100 \mu \mathrm{M}$ apigenin as compared to untreated controls. However, K562/IMA3 cells showed resistance to apigenin as compared to K562 cells because, only 1.1- and 2.2-fold increases have been detected in apoptotic K562/IMA3 cell population, whereas there were 2.6and 4.2-fold increases in percentage of apoptotic K562 cells. To elucidate the molecular mechanism of apigenin induced apoptosis in imatinib-sensitive and resistant cells, we first checked the effect of apigenin on MMP. The JC-1 dye-based assay results revealed that apigenin caused loss of MMP in a dose-dependent manner in both cells. It is very well known that mitochondria is an important player for all apoptotic pathways and it is widely accepted that alterations in the structure and function of mitochondria play an important role in caspase-dependent apoptosis. Caspase-3 functions in the last step of caspase-mediated apoptosis and is responsible for the properties of apoptotic cells (such as DNA fragmentation) (19). Based on this knowledge, we next checked the activation of caspase- 3 enzyme in apigenin treated cells. Our data demonstrated that apigenin increased caspase-3 activities of both cell types in a dose-dependent manner as compared to untreated controls. Taken together, we can conclude that apigenin may induce apoptosis in both cells through the loss of MMP and caspase- 3 activation. However, it was clearly indicated in this study that K562/IMA3 cells required higher doses of apigenin than K562 cells for antiproliferative and apoptotic effects. Similar to our results, apigenin was shown to induce mitochondial depolarization and caspase activation in HL-60 acute promyelocytic leukemia cells (16). We also investigated the cytostatic property of apigenin on CML cells and observed that the treatment of K562 CML cells with apigenin resulted in G2/M phase arrest especially at high concentrations. Many studies have reported that apigenin blocks cell cycle progression in cancer cells, however, depending on the cell type, apigenin can arrest the cell cycle in different phases. For instance, it caused G2/M arrest in colon carcinoma (25). Nevertheless, in human prostate cancer, LNCap and PC-3 cells, apigenin induced cell cycle arrest in G0/G1 (26). The results of our study extend these observations that, depending on the cyclins affected, responses may be substantially different.

In this study, we also performed microarray analysis in K562 and K562/IMA3 cells to identify the genes and networks that are involved in apigenin-induced apoptosis. For this purpose, heat map analysis was performed to cluster the genes in K562 and K562/IMA3 cells exposed to 50 and $100 \mu \mathrm{M}$ apigenin. As indicated in the result part, both cell types responded to apigenin with changes in the expression levels and numbers of genes. Moreover, the number of altered genes showed differences between 50 and $100 \mu \mathrm{M}$ apigenin-treated cells while there were some common genes. For instance, UNC5A and SCARA5 were some common altered genes with different expression levels in 50 and $100 \mu \mathrm{M}$ apigenin-treated K562 cells. UNC5A is associated with tumorigenesis in nonneuronal cells and function as a tumor supressor $(27,28)$. Several studies showed that UNC5A is downregulated in human breast, lung, and colorecteral cancers and it was found to induce apoptosis in p53-dependent manner $(28,29)$. In our study, this gene was the most upregulated one in both 50 and $100 \mu \mathrm{M}$ apigenin-treated K562 cells and it could be tought to cause apigenin induced cell death. Similarly, it is known that SCARA5 gene has tumor suppressor function (30) and its upregulation could be related to apigenin mediated cell death in K562 cells. Besides UNC5A and SCARA5, genes summarized in Table 1 have been shown to possess different roles in carcinogenesis depending on their expression status (31-33). The study also concluded that apigenin treatment could modulate the phosphatidylinositol signaling system, which has key regulatory functions in cell survival, proliferation, and apoptosis, in both 50 and $100 \mu \mathrm{M}$ apigenin-treated K562 cells due to downregulation of some players of this pathway such as DGKA in response to apigenin treatment. Therefore, the downregulation of this pathway could be responsible for apigenin-mediated apoptosis of K562 cells. On the other hand, apigenin treatment altered the expression levels of several genes in K562/IMA3 cells as compared to untreated controls (summarized in Table 2). For example, HAGH gene, encoding glyoxylase II enzyme (which is a member of glyoxalase pathway), was the most upregulated one in both 50 and $100 \mu \mathrm{M}$ apigenin treated K562/IMA3 cells and it is known that the overexpression of this gene is related to drug and apoptosis resistance in several cancer cells such as leukemia, lung, and breast cancer (34). Therefore, K562/IMA3 cells might show resistance to apigenin-induced apoptosis as compared to sensitive K562 cells due to overexpression of HAGH. Similarly, IL15RA and ENTPD1 were the examples of overexpressed genes in K562/IMA3 cells and their 
upregulation is known to induce growth and proliferation of cancer cells $(35,36)$. Based on this knowledge, we concluded that their upregulation might be responsible for survival of the resistant cells after apigenin treatment. In contrast to K562 cells, phosphatidylinositol signaling system was thought to be activated following apigenin treatment in K652/IMA-3 cells since DGKI, downstream player in this pathway, was upregulated in 50 and $100 \mu \mathrm{M}$ apigenin treatment. DGKI overexpression has been displayed to induce cell growth (37) and its modulation might be related to lower apoptotic effect of apigenin on K562/IMA3 cells. Besides the above genes, genes summarized in Table 2 have been shown to be related with tumor growth and drug resistance depending on their expression status $(30,38,39)$. As explained in the Results section, K562/IMA3 cells were more resistant to apigenin treatment than K562 cells in terms of cytotoxic and apoptotic effects and microarray data supported these results. Therefore, discussed genes in K562 and K562/IMA3 cells may warrant further investigation as a candidate target of apigenin. In addition to gene clustering, IPA tools were used to get an idea about networks with known biological pathways. These networks were found to be associated with the cell survival, proliferation, cell death, cell cycle, and cell signalling pathways. Apigenin might display its anticarcinogenic property in several cancer types by modulating cell signalling pathways such as phosphatidylinositol 3-Kinase/Akt-dependent pathway, MAPK pathway, and cell cycle related pathways (12).

In conclusion, the results of this study indicated that apigenin may have therapeutic potential in imatinib-sensitive and imatinib-resistant CML cells due to induction of apoptosis, inhibition of cell proliferation and cell-cyle arrest. Moreover, the genetic networks derived from this study illuminate some of the biological pathways affected by apigenin treatment while providing a proof of principle for identifying candidate genes that might be targeted for CML therapy. Furthermore, in vivo administration of most effective concentrations of apigenin into K562 mice xenografts could be helpful to understand the possibility that apigenin may have clinical implications and might be further tested for incorporating in leukemia treatment regimens.

\section{NOTE}

Soner Solmaz and Aysun Adan Gokbulut contributed equally to this article.

\section{ACKNOWLEDGMENTS}

We thank Biotechnology and Bioengineering Application and Research Center staff of İzmir Institute of Technology for their help and technical support.

\section{REFERENCES}

1. Quinta's-Cardama A, and Cortes JE: Molecular biology of bcrabl1-positive chronic myeloid leukemia. Blood 113, 1619-1630, 2009.

2. Faderl S, Talpaz M, Estrov Z, O'Brien S, Kurzrock R, et al.: The biology of chronic myeloid leukemia. N Engl J Med 341, 164-172, 1999.
3. Di Bacco A, Keeshan K, McKenna SL, and Cotter TG: Molecular abnormalities in chronic myeloid leukemia: deregulation of cell growth and apoptosis. Oncologist 5, 405-415, 2000.

4. Frazer R, Irvine AE, and McMullin MF: Chronic myeloid leukaemia in the 21st century. Ulster Med J 76, 8-17, 2007.

5. Hurtado R, Vargas P, and Cortes J: Chronic myeloid leukemia current concepts in physiopathology and treatment. T Cancerologia 2, 137-147, 2007.

6. Quintás-Cardama A, Kantarjian HM, and Cortes JE: Mechanisms of primary and secondary resistance to imatinib in chronic myeloid leukemia. Cancer Control 16, 122-131, 2009.

7. Ramirez $\mathrm{P}$ and DiPersio JF : Therapy options in imatinib failures. Oncologist 13, 424-434, 2008.

8. Melo JV and Chuah C: Novel agents in CML therapy: tyrosine kinase inhibitors and beyond. Hematology Am Soc Hematol Educ Program 2008, 427-435, 2008.

9. Santos FP and Ravandi F: Advances in treatment of chronic myelogenous leukemia new treatment options with tyrosine kinase inhibitors. Leuk Lymphoma 2, 16-26, 2009.

10. Monasterio A, Urdaci MC, Pinchuk IV, Lopez-Moratalla N, and MartinezIrujo JJ: Flavonoids induce apoptosis in human leukemia U937 cells through caspase- and caspase-calpain-dependent pathways. Nutrition and Cancer 50, 90-100, 2004.

11. Patel D, Shukla S, and Gupta S: Apigenin and cancer chemoprevention: Progress, potential and promise. International Journal of Oncology 30, 233-245, 2007.

12. Shukla $S$ and Gupta S: Apigenin: A promising molecule for cancer prevention. Pharm Res 27, 962-978, 2010.

13. Ruela-de-Sousa RR, Fuhler GM, Blom N, Ferreira CV, Aoyama H, et al.: Cytotoxicity of Apigenin on leukemia cell lines: implications for prevention and therapy. Cell Death Dis 1, 1-19, 2010.

14. Chan LP, Chou TH, Ding HY, Chen PR, Chiang FY, et al.: Apigenin induces apoptosis via tumor necrosis factor receptor- and Bcl-2-mediated pathway and enhances susceptibility of head and neck squamous cell carcinoma to 5 fluorouracil and cisplatin. Biochimica et Biophysica Acta 1820, 1081-1091, 2012.

15. Iwasaki R, Ito K, Ishida $\mathrm{T}$, Hamanoue $\mathrm{M}$, Adachi $\mathrm{S}$, et al.: Catechin, green tea component, causes caspase-independent necrosis-like cell death in chronic myelogenous leukemia. Cancer Sci 100, 349-356, 2009.

16. Vargo MA, Voss OH, Poustka F, Cardounel AJ, Grotewold E, et al.: Apigenin-induced-apoptosis is mediated by the activation of PKCdelta and caspases in leukemia cells. Biochem Pharmacol 72, 681-692, 2006.

17. Lu HF, Chie YJ, Yang MS, Lee CS, Fu JJ, et al.: Apigenin induces caspasedependent apoptosis in human lung cancer A549 cells through Bax- and Bcl-2-triggered mitochondrial pathway. Int J Oncol 36, 1477-1484, 2010.

18. Choi EJ and Kim GH: Apigenin induces apoptosis through a mitochondria/caspase-pathway in human breast cancer MDA-MB-453 cells. J Clin Biochem Nutr 44, 260-265, 2009.

19. Wang IK, Lin-Shiau SY, and Lin JK: Induction of apoptosis by apigenin and related flavonoids through cytochrome c release and activation of caspase-9 and caspase-3 in leukaemia HL-60 cells. Eur J Cancer 35, 1517-1525, 1999.

20. Gonzalez-Mejia ME, Voss OH, Murnan EJ, and Doseff AI: Apigenininduced apoptosis of leukemia cells is mediated by a bimodal and differentially regulated residue-specific phosphorylation of heat-shock protein-27. Cell Death Dis 1, e64, 2010.

21. Salas A, Ponnusamy S, Senkal CE, Meyers MA, Selvam SP, et al.: Sphingosine kinase-1 and sphingosine 1-phosphate receptor 2 mediate Bcr-Abl1 stability and drug resistance by modulation of protein phosphatase $2 \mathrm{~A}$. Blood 117, 5941-5952, 2011.

22. Baran Y, Bielawski J, Ogretmen B, and Gunduz U: Inhibition of glucosylceramide synthase by PDMP resensitizes multidrug-resistant human chronic myeloid leukemia cells to imatinib. Journal of Cancer Research and Clinical Oncology 137, 1535-1544, 2011. 
23. Avc1 CB, Gunduz C, Baran Y, Sahin F, Yilmaz S, et al.: Caffeic acid phenethyl esther triggers apoptosis through induction of loss of mitochondrial membrane potential in CCRF-CEM. Journal of Cancer Research and Clinical Oncology 137, 41-47, 2011.

24. Chen D, Daniel KG, Chen MS, Kuhn DJ, Landis-Piwowar KR, et al.: Dietary flavonoids as proteasome inhibitors and apoptosis inducers in human leukemia cells. Biochem Pharmacol 69, 1421-1432, 2005.

25. Wang W, Heideman L, Chung CS, Pelling JC, Koehler KJ, et al.: Cell-cycle arrest at G2/M and growth inhibition by apigenin in human colon carcinoma cell lines. Mol Carcinog 28, 102-110, 2000.

26. Shukla $S$ and Gupta S: Apigenin-induced cell cycle arrest is mediated by modulation of MAPK, PI3K-Akt, and loss of cyclin D1 associated retinoblastoma dephosphorylation in human prostate cancer cells. Cell Cycle 6, 1102-1114, 2007.

27. Arakawa H: Netrin-1 and its receptors in tumorigenesis. Nat Ev Cancer 4, 978-987, 2004.

28. Thiebault K, Mazelin L, Pays L, Llambi F, Joly MO, et al.: The netrin1 receptors $\mathrm{UNC} 5 \mathrm{H}$ are putative tumor suppressors controlling cell death commitment. Proc Natl Acad Sci USA 100, 4173-4178, 2003.

29. Miyamoto Y, Futamura M, Kitamura N, Nakamura Y, Baba H, et al.: Identification of UNC5A as a novel transcriptional target of tumor suppressor p53 and a regulator of apoptosis. Int J Oncol. 36, 1253-1260, 2010.

30. Huang J, Zheng DL, Qin FS, Cheng N, Chen H, et al.: Genetic and epigenetic silencing of SCARA5 may contribute to human hepatocellular carcinoma by activating FAK signaling. J Clin Invest 120, 223-241, 2010.

31. Tonks A, Pearn L, Musson M, Gilkes A, Mills KI, et al.: Transcriptional dysregulation mediated by RUNX1-RUNX1T1 in normal human progenitor cells and in acute myeloid leukaemia. Leukemia 21, 2495-2505, 2007.

32. Cimmino A, Calin GA, Fabbri M, Iorio MV, Ferracin M, et al.: miR-15 and miR-16 induce apoptosis by targeting BCL2. Proc Natl Acad Sci U S A 102, 13944-13949, 2005.

33. Katoh $\mathrm{M}$ and Katoh $\mathrm{M}$ : Identification and characterization of human SNAIL3 (SNAI3) gene in silico. Int J Mol Med 11, 383-388, 2003.

34. Tsuruo T, Naito M, Tomida A, Fujita N, Mashima T, et al.: Molecular targeting therapy of cancer: drug resistance, apoptosis and survival signal. Cancer Sc. 294, 15-21, 2003.

35. Chen J, Petrus M, Bamford R, Shih JH, Morris JC, et al.: Increased serum soluble IL-15R $\alpha$ levels in T-cell large granular lymphocyte leukemia. Blood 119, 137-143, 2012.

36. Loos M, Künzli B, and Friess H: Quantitation of CD39 gene expression in pancreatic tissue by real-time polymerase chain reaction. Methods $\mathrm{Mol}$ Biol 576, 351-362, 2010.

37. Baldanzi G, Pietronave S, Locarno D, Merlin S, Porporato P, et al.: Diacylglycerol kinases are essential for hepatocyte growth factor-dependent proliferation and motility of Kaposi's sarcoma cells. Cancer Sci 10, 1329-1336, 2011.

38. Plasschaert SL, de Bont ES, Boezen M, vander Kolk DM, Daenen SM, et al.: Expression of multidrug resistance-associated proteins predicts prognosis in childhood and adult acute lymphoblastic leukemia. Clin Cancer Res 11, 8661-8668, 2005.

39. Sohail A, Sun Q, Zhao H, Bernardo MM, Cho JA, et al.: MT4-(MMP17) and MT6-MMP (MMP25), A unique set of membrane-anchored matrix metalloproteinases: properties and expression in cancer. Cancer Metastasis Rev 27, 289-302, 2008. 